\title{
CDISC SDTM Malaria Findings About Test Code Terminology
}

National Cancer Institute

\section{Source}

National Cancer Institute. CDISC SDTM Malaria Findings About Test Code Terminology. NCI Thesaurus. Code C132320.

Terminology associated with the malaria findings about test code codelist of the Clinical Data Interchange Standards Consortium (CDISC) Study Data Tabulation Model (SDT M). 